\title{
Paleocene agglutinated foraminifera from Jabal Mundassa, Al Ain area, United Arab Emirates
}

\author{
Haidar Salim ANAN
}

Emeritus, Prof. of stratigraphy and micropaleontology, Gaza P.O. Box 1126, Palestine; profanan@gmail.com

Anan, H.S. 2015. Paleocene agglutinated foraminifera from Jabal Mundassa, Al Ain area, United Arab Emirates. [Foraminíferos aglutinados del Paleoceno en Jabal Mundassa, Al Ain area, Emiratos Árabes Unidos]. Spanish Journal of Palaeontology, 30 (2), 239-256.

Manuscript received 20 January 2015

Manuscript accepted 13 May 2015

(C) Sociedad Española de Paleontología ISSN 2255-0550

\begin{abstract}
The Paleocene succession of Jabal Mundassa, Al Ain area, United Arab Emirates (UAE) contains prolific and wellpreserved species of agglutinated, planktic and calcareous benthic foraminifera at the Danian/Selandian (D/S) transition. This succession is considered as the only one that has Danian sediments in the Al Ain area. The present study is deals with the taxonomy, palaeogeography and stratigraphic distribution of twenty-six agglutinated benthic species at Jabal Mundassa and other Paleocene outcrops localities in the Tethys.
\end{abstract}

Keywords: Danian, Selandian, Mundassa, United Arab Emirates (UAE).

\section{RESUMEN}

La sucesión del Paleoceno en Jabal Mundassa, zona de Al Ain, Emiratos Árabes Unidos (EAU), contiene especies prolíficas bien conservadas de foraminíferos aglutinados planctónicos y bentónicos calcáreos, de la transición Daniense/Selandiense. Esta sucesión se considera como el único afloramiento que tiene sedimentos del Daniense en el área de Al Ain. Este estudio se enfoca en la taxonomía, paleogeografía y distribución estratigráfica de veintiséis especies de foraminíferos bentónicos aglutinados, que pertenecen a diecinueve géneros. La paleontología, la paleogeografía y distribución estratigráfica de la fauna identificada en Jabal Mundassa es comparada con la de otros afloramientos del Paleoceno en el Mar del Tetis.

Palabras clave: Daniense, Selandiense, Mundassa, Emiratos Árabes Unidos (EAU). 


\section{INTRODUCTION}

The present paper is a part of a comprehensive study concerned with the complete record of smaller benthic foraminifera of the post-nappe Upper Cretaceous and Paleogene sediments in the United Arab Emirates (UAE). The micropaleontological content of this succession was treated by many authors: Cherif et al. (1992) studied the Middle Eocene-Miocene benthic foraminifera of Jabal (mountain) Hafit, Al Ain area (Fig. 1), and recorded 31 benthic species (7 of them are agglutinated). Anan et al. (1992) studied the Lower Eocene-Oligocene succession of Jabal Hafit and identified 69 species of planktic and 19 species of larger benthic foraminifera. Anan (1993a) recorded 70 benthic species (15 of them are agglutinated) from the Middle-Upper Paleocene beds in J. Malaqet, Al Ain area. Anan (1993b) recorded 28 benthic species (19 of them are agglutinated) from the MaastrichtianPaleocene succession of the Qarn El Barr section, Al Dhayd area, central north UAE. Anan (1996) recorded 27 benthic species ( 8 of them are agglutinated) from the Lower Eocene rocks of J. Hafit. Abdelghany (2003) recorded 27 benthic species (4 of them are agglutinated) from the Campanian-Maastrichtian rocks of the Qarn El Barr and Malaqet sections, UAE. Anan (2005a) recorded 15 agglutinated species from Middle-Upper Eocene rocks of J. Hafit. Anan (2007) recorded 42 benthic species (5 of them are agglutinated) from the upper Eocene rocks of J. Malaqet. In the present study, 26 agglutinated species at the $\mathrm{D} / \mathrm{S}$ transition are identified ( 21 of them are illustrated). The micropaleontology, paleogeography, and stratigraphy of the Paleocene rocks of the studied section, UAE, and other localities in the Tethys are also presented.

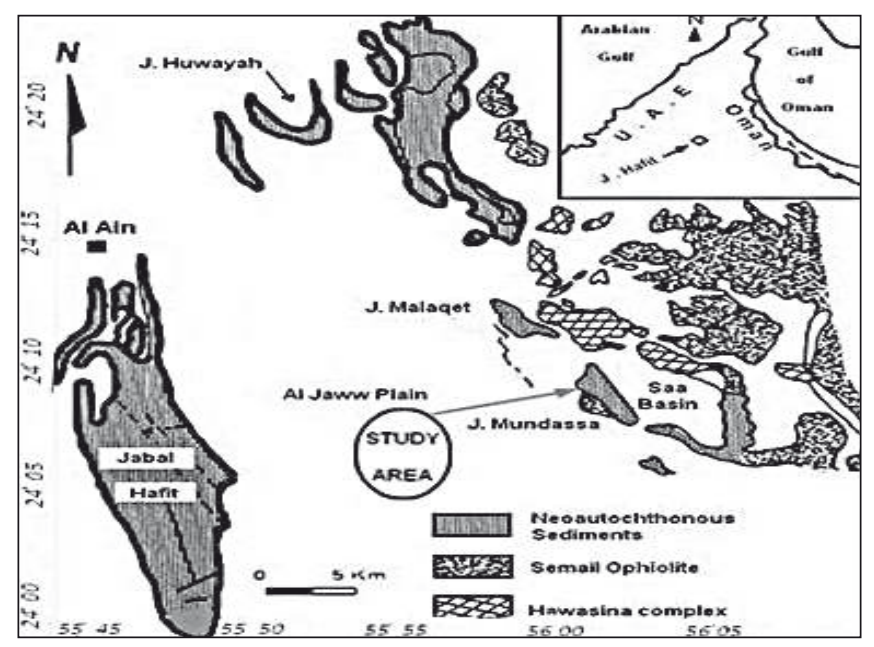

Figure 1. Location map of the study section at Jabal Mundassa, Al Ain area, UAE.

\section{GEOLOGY AND STRATIGRAPHY OF THE STUDIED SECTION}

The upper Maastrichtian to Paleogene (M/P) post-nappe rocks crop out as a discontinuous belt in jabals (mountains) and qarns (hills) around the western front of the Northern Oman Mountains (NOM) in the UAE. The folded anticlines of J. Mundassa and J. Malaqet in the Al Ain area are parts of the NOM and located approximately 25 $\mathrm{km}$ south of Al Ain city (UAE), and about $20 \mathrm{~km}$ east of J. Hafit. These jabals are related in the eastern side of the Al Jaww Plain, near the border with the Sultanate of Oman (Fig. 1). The pre-Maastrichtian Semail Ophiolite (SO) forms the core of the breached anticlines of J. Mundassa and J. Malaqet. During the last stage of the emplacement of the Semail Ophiolite onto the passive continental margin of the Arabian platform, several foredeep basins were developed including the Ras Al Khaima basin and the Mundassa basin. These basins hosted deposition of a Maastrichtian-Paleogene (M/P) sedimentary succession, which unconformably overly deposits that deformed later by contemporaneous thrust faults and folds. The $\mathrm{D} / \mathrm{S}$ transition is attributed to the shaley marl neoautochthonous sediments belonging to the Mundassa Member of the Muthaymimah Formation, which are nonconformably overlying the Pre-Maastrichtian allochthonus Semail Ophiolite (serpentinites and serpentinized peridotites). This depositional gap is most probably due to submarine erosion not to subaerial denudation, and corresponds to an episode of tectonic activity that exists in most localities in the world. The neoautochthonous and the underlying allochthonus rocks were deformed by post-obduction compression and formed folds and thrusted fault belts along the western flank of the Northern Oman Mountains (Warrak, 1996). In the region have been carried out the outcrops of these belts comprise many jabals in the $\mathrm{Al}$ Ain area (i.e., J. Mundassa, J. Malaqet, J. Hafit, Fig. 1).

The Paleocene shaley marl post-nappe sediments, which unconformably overlie the obducted Semail Ophiolite in the J. Mundassa anticline (Fig. 2) are related to the Mundassa Member (of Hamdan \& Anan, 1993 and Anan, 1993a) of the Muthaymimah Formation (of Nolan et al., 1990), but to the Mundassa Formation (of Noweir \& Eloutefi, 1997), while it was attributed to the lower part of Malaqet Formation of J. Malaqet (in Boukhary et al., 2003). The shaley marl of J. Mundassa was attributed to the Late Paleocene by Noweir \& Eloutefi (1997), but it referred to the Early-Middle Paleocene based on the planktic foraminiferal biozonation.

The gypsiferous green shale in J. Malaqet, which unconformably overlies the Late Maastrichtian Simsima Formation, was observed to the Middle Paleocene by Hamdan \& Anan (1993), Anan \& Hamdan (1993) and Anan (1993a), but was attributed to the Late Paleocene by Noweir \& Eloutefi (1997) and Boukhary et al. (2003). On 
the other hand, Speijer (2003) noted that the D/S transition in Egypt is marked by a black shale bed rich in organic carbon and fish remains, strongly dominated by anomalous foraminiferal assemblages, and defined as the "Neo-duwi event", while in Tunisia, a palaeoenvironmental change is recorded during the same interval although it was not marked by a black shale bed. In the section presented in this study, J. Mundassa in UAE, neither marked black shale bed in this interval nor Neoeponides duwi are recorded. In total 26 agglutinated benthic foraminiferal species are recorded, 21 of which are illustrated in Figure 4 from the D/S transition (Early-Middle Paleocene, P1a-P3) of the shaley marl succession in J. Mundassa. Based on the planktic foraminiferal zonation the duration of the hiatus at the Cretaceous/Paleogene $(\mathrm{K} / \mathrm{P})$ boundary includes the two earliest Danian biozones (P0 and Pa, about 0.02 Ma, Fig. 2).

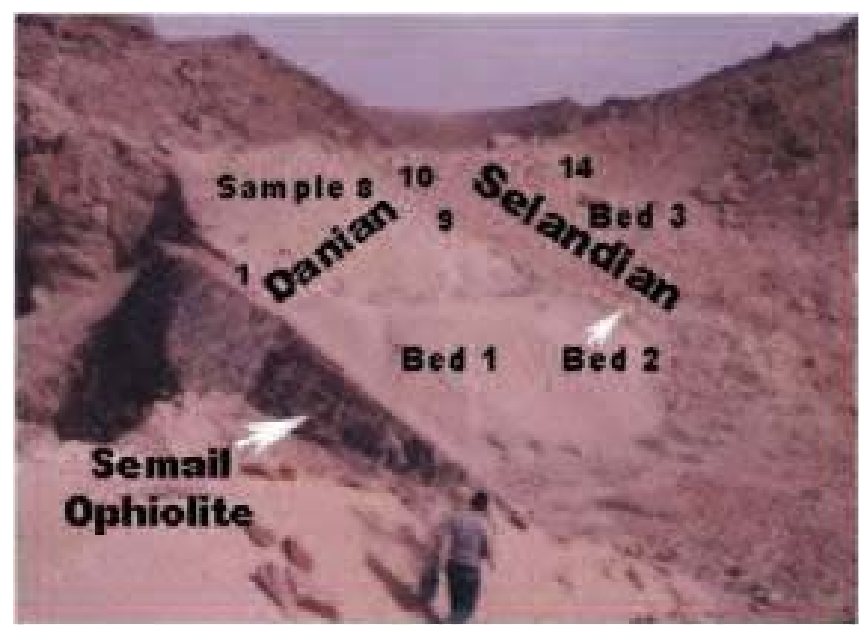

Figure 2. View of the Paleocene sediments (Danian-Selandian transition, Mundassa Member of the Muthaymimah Formation) which nonconformably overly the obducted pre-Maastrichtian Semail Ophiolite.

\section{MATERIAL OF STUDY}

Fourteen samples from the shaley marl succession of $\mathrm{J}$. Mundassa (samples 1-14, with about 26 m thick interval, composed of beds 1-3 which contain a yellow brown hard ledge bed no. 2 with sample 9) were collected from the exposed neoautochthonous Paleocene rocks of the Mundassa Member of the Muthaymimah Formation, which nonconformably rest on the peneplained allochthonus PreMaastrichtian Semail Ophiolite (Fig. 3).

\subsection{Systematic palaeontology}

This study concentrates on the taxonomy and palaeogeographic distribution of twenty-six identified agglutinated benthic foraminiferal species (belonging to nineteen genera), and twenty one of them are illustrated in Figure 4 . The suprageneric systematics of the agglutinated foraminifera by Kaminski (2004) is used herein.

Class FORAMINIFERA d'Orbigny, 1826

Order ASTRORHIZIDA Lankester, 1855

Suborder ASTRORHIZINA Lankester, 1855

Superfamily ASTRORHIZACEA Brady, 1881

Family Bathysiphonidae Avnimelech, 1952

Subfamily Bathysiphoninae Avnimelech, 1952

Genus Bathysiphon Sars, 1872

Type species Bathysiphon filiformis Sars, 1872

Bathysiphon eocenicus Cushman \& Hanna, 1927

(Fig. 4.1)

1927 Bathysiphon eocenicus Cushman \& Hanna, p. 210, pl. 13, figs. 2, 3.

1994 Bathysiphon eocenicus; Bolli et al., p. 65, fig. 18. 3.

2005a Bathysiphon eocenicus; Anan, p. 18, pl. 1, fig. 1.

The species was originally described from the Eocene of California. It is also recorded from Paleocene-Eocene rocks of other localities in the Tethys (i.e., Ecuador, Trinidad, Italy, Egypt, UAE), as well as from the Paleocene sediments of the J. Mundassa section.

\section{Bathysiphon paleocenicus El-Dawy, 2001}

(Fig. 4.2)

2001 Bathysiphon paleocenicus El-Dawy, p. 42, pl. 1, fig. 1 .

2012 Bathysiphon paleocenicus; Anan, p. 63, pl. 1, fig. 3 .

This species was originally described from the upper Paleocene deposits of central Egypt. It was also recorded for the first time outside Egypt by Anan (2012) in the Danian-Selandian transition of J. Mundassa. The latter author (op. cit.) also noted that the middle-late Eocene Bathysiphon saidi of Anan (1994, 2005a) were recorded from Egypt and UAE is most probably the youngest form of B. paleocenicus.

Genus Nothia Pflaumann, 1964

Type species Rhizammina grilli Noth, 1951

Nothia excelsa (Grzybowski, 1898)

(Fig. 4.3) 


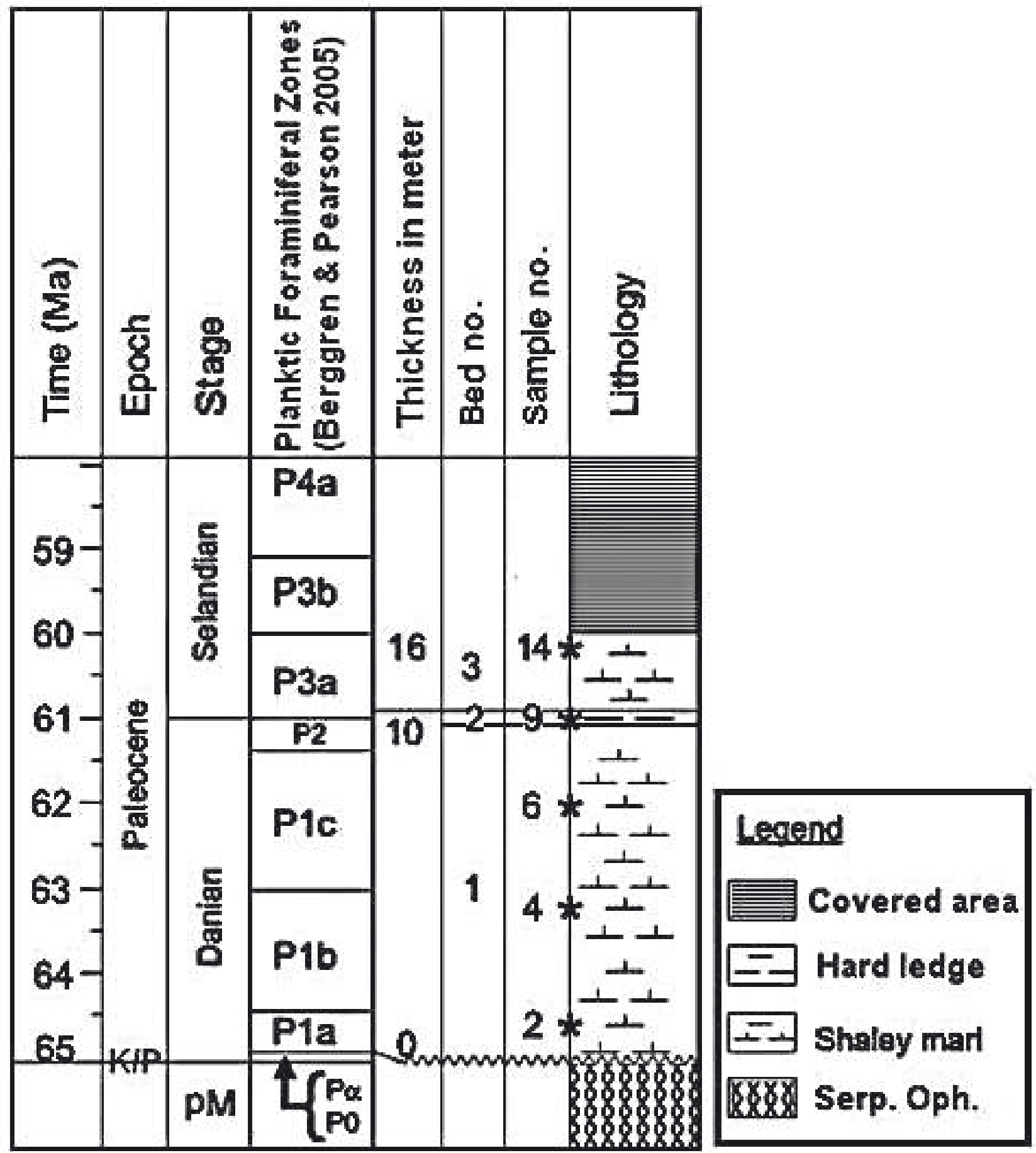

Figure 3. The stratigraphic log of the Danian-Selandian transition in the eastern limb of J. Mundassa anticline, Al Ain area, UAE ( $\mathrm{pM}=$ pre-Maastrichtian, $\mathrm{K} / \mathrm{P}=$ Cretaceous/Paleogene boundary, Serp. Oph.= serpentine Semail Ophiolite).

1898 Dendrophrya excelsa Grzybowski, p. 272, pl. 10, figs. 1-4.

1972 Dendrophrya excelsa; Hanzlíková, p. 32, pl. 2, fig. 6.

1977 Dendrophrya excelsa; Krasheninnikov \& Pflaumann, p. 567, pl. 1, fig. 7.

1981 Dendrophrya excelsa; Morgiel \& Olszewska, p. 7 , pl. 1 , figs. 5, 6 .
1992 Nothia excelsa; Geroch \& Kaminski, p. 265, pl. 1, fig. 2.

1993 Dendrophrya excelsa; Kuhnt \& Kaminski, p. 72, pl. 1, fig. 2 .

1996 Nothia excelsa; Kuhnt \& Collins, p. 212.

2005 Nothia excelsa; Kaminski \& Gradstein, p. 106, text-fig. 2, pl. 2a, 1-9, pl. 2b, 1-11.

2006 Nothia excelsa; Cieszkowski et al., p. 208, fig. 6 A. 
2009 Nothia excelsa; Kender et al., p. 493, pl. 1, fig. 5. 2013 Nothia excelsa; Bindiu et al., p. 122, fig. 4. 1-3.

Loeblich \& Tappan (1987) noted that the Late Cretaceous-Paleogene genus Nothia commonly has elongated, tubular, and may branch sparsely and irregular test, while the early stage of the genus Dendrophrya consists of a hemispherical test. It was recorded from many parts of the Tethys: i.e., South Atlantic, Spain, Poland, the Czech Republic, Romania, and Angola. Nothia excelsa is recorded from the Danian strata of J. Mundassa, for the first time in UAE.

Suborder AMMODISCINA Mikhalevich, 1980

Superfamily AMMODISCACEA Reuss, 1862

Family Ammodiscidae Reuss, 1862

Subfamily Ammodiscinae Reuss, 1862

Genus Ammodiscus Reuss, 1862

Type species Ammodiscus infimus Bornemann, 1874

Ammodiscus angustus (Friedberg, 1901)

(Fig. 4.4)

1901 Cornuspira angusta Friedberg, p. 178, pl. 1, fig. 8 . 1987 Ammodiscus angustus; Loeblich \& Tappan, p. 47, pl. 36, figs. 5-9.

1999 Ammodiscus angustus; Ansorge et al., p. 235.

This species is characterized by having a globular proloculus followed by planispirally enrolled and undivided tubular chamber. It is recorded from the Paleocene rocks of J. Mundassa, for the first time in UAE.

\section{Ammodiscus cretaceus (Reuss, 1845)}

(Fig. 4.5)

1845 Operculina cretacea Reuss, p. 35, pl. 13, figs. 64, 65 .

1977 Ammodiscus cretaceus; Sliter, p. 677, pl. 1, fig. 3. 1988 Ammodiscus cretaceous; Kaiho, p. 554, fig. 1. 23, p. 556, fig. 2. 11.

1989 Ammodiscus cretaceus; Hulsbos et al., p. 266, pl. 1, fig. 9.

1993 Ammodiscus cretaceus; Kuhnt \& Kaminski, p. 145, pl. 2, fig. 1.

1993 Ammodiscus cretaceus; Hewaidy \& Al-Hitmi, p. 471, pl. 1, figs. 1, 2 .

1999 Ammodiscus cretaceus; Ansorge et al., p. 235.

2004 Ammodiscus cretaceus; Galeotti et al., p. 94, pl. 2, fig. 1

2005 Ammodiscus cretaceus; Kaminski \& Gradstein, p. 106, text-fig. 14, pl. 14, figs. 1-10. 2005b Ammodiscus cretaceus; Anan, p. 78, pl. 1, fig. 1. 2009 Ammodiscus cretaceus; Kender et al., p. 495, pl. 1, fig. 16.

Kuhnt \& Kaminski (1993) lumped Ammodiscus glabratus in A. cretaceus which is acceptable here. This cosmopolitan Paleocene-Miocene species was originally recorded from the Eocene of California (USA), and later from many parts of the Tethys: Ecuador, South Atlantic, Norwegian Sea, Italy, Trinidad, Spain, Poland, Bulgaria, Romania, Angola, Tunisia, Egypt, Qatar, UAE, Japan and New Zealand. It is also present in the Paleocene of J. Mundassa.

Subfamily Usbekistaniinae Vyalov, 1968

Genus Glomospira Rzehak, 1885

Type species Trochammina squamata Jones \& Parker var. gordialis Jones \& Parker, 1860

Glomospira gordialis (Jones \& Parker, 1860)

(Fig. 4.6)

1860 Trochammina squamata Jones \& Parker var. gordialis Jones \& Parker, p. 304.

1977 Glomospira gordialis; Sliter, p. 677, pl. 1, fig. 7.

1978 Glomospira charoides; Proto Decima \& Bolli, p. 794 , pl. 1, fig. 2 .

2004 Glomospira charoides; Galeotti et al., p. 94, pl. 2, fig. 5

2005 Glomospira charoides; Kaminski \& Gradstein, p. 181 , text-fig. 25 , pl. 25 , figs. $1-8$.

2008 Glomospira charoides; Filipescu \& Kaminski, p. 27 , pl. 2 , fig. 6 .

2009 Glomospira gordialis; Kender et al., p. 494, pl. 2, fig. 11.

2013 Glomospira gordialis; Bindiu et al., p. 123, fig. 5. 3 .

Loeblich \& Tappan (1987) noted that the genus Glomospira has a streptospirally coiled. It is coiled like Repmanina in the early portion (trochospirally coiled test about a straight axis), and the latter portion is coiled glomospirally (planispiral whorls inclined at a small angle to each other). This has been shown by Bender (1995). The author believes that the two subspecies gordialis and charoides of Jones \& Parker (1860) are difficult to differentiate from each other. Glomospira gordialis is a cosmopolitan form recorded from upper Cretaceous to Recent sediments, occurring in many parts of the Tethys: USA, Canada, Spain, Russia, Italy, Ukraine, Angola, Tunisia, Egypt. It is also reported from the Paleocene rocks of J. Mundassa, for the first time in UAE. 
Genus Repmanina Suleymanov, 1966

Type species Trochammina squamata Jones \& Parker var. charoides Jones \& Parker, 1860

\section{Repmanina sp.}

(Fig. 4.7)

Loeblich \& Tappan (1987) noted that the genus Repmanina has regular trochospirally coiled test about a straight axis and forms a depressed crown-like coiled in outline, chambers have sharp edges with a smooth wall. This species differs from Glomospira gordialis by its regular and depressed crown coiled in outline, the center of the test is wider than the start and end of its coiling. It is recorded from the Selandian rocks of J. Mundassa.

Order LITUOLIDA Lankester, 1885

Suborder HORMOSININA Mikhalevich, 1980

Superfamily POLYCHASMININAE Kaminski, 2004

Family Glaucoamminidae Saidova, 1981

Genus Psammolingulina Silvestri, 1904

Type species Lingulina papillosa Neugeboren, 1856

\section{Psammolingulina sp.}

(Fig. 4.8)

This species has an elongated rectilinear uniserial test of inflated globular equal height chambers and rounded peripheral with terminal slit-like aperture, strongly depressed sutures, and wall of agglutinated coarse quartz particles giving a rough surface. It differs from the type species of the Miocene-Pliocene P. papillosa Neugeboren, 1856 by its more inflated chambers and its older occurrence at the Danian-Selandian transition, and in having more depressed sutures.

Suborder LITUOLINA Lankester, 1885

Superfamily LITUOLACEA de Blainville, 1827

Family Lituolidae de Blainville, 1827

Subfamily Ammomarginulinae Podobina, 1978

Genus Ammobaculites Cushman, 1910

Type species Spirolina agglutinans d'Orbigny, 1846

Ammobaculites schwageri Said \& Kenawy, 1956

1956 Ammobaculites schwageri Said \& Kenawy, p. 121, pl. 1, fig. 8 .
This species is characterized by its planispirally nonumbilicate closed coiled initial stage followed by uncoiled chambers in the later stage with a smoothly finished agglutinated wall. It was originally recorded from the Paleocene rocks of Sinai, Egypt, and from the Paleocene rocks of $\mathrm{J}$. Mundassa, for the first time in UAE.

\section{Superfamily HAPLOPHRAGMIACEA Eimer \&} Fickert, 1899

Family Ammosphaeroidinidae Cushman, 1927

Subfamily Ammosphaeroidininae Cushman, 1927

Genus Ammosphaeroidina Cushman, 1910

Type species Haplophragmium sphaeroidiniforme Brady, 1884

Ammosphaeroidina pseudopauciloculata (Mjatliuk, 1966) (Fig. 4.9)

1966 Cystamminella pseudopauciloculata Mjatliuk, p. 264, pl. 1, figs. 5-8, pl. 2, fig.6, pl. 3, fig. 3 .

1987 Ammosphaeroidina pseudopauciloculata; Loeblich \& Tappan, p. 81, pl. 67, figs. 8-10.

1993 Ammosphaeroidina pseudopauciloculata; Kuhnt \& Kaminski, p. 72, pl. 5, fig. 10.

1994 Ammosphaeroidina pseudopanciloculata; Kender et al., p. 501, pl. 6, fig. 7.

2004 Ammosphaeroidina pseudopauciloculata; Galeotti et al., p. 94, Pl.4, fig. 1

2005 Ammosphaeroidina pseudopauciloculata; Kaminski \& Gradstein, p. 376, text-fig. 87, pl. 87a, figs. 1-5, pl. 87b, figs. 1-10.

2006 Ammosphaeroidina pseudopauciloculata; Cieszkowski et al., p. 209, pl. 7, fig. G.

This species is characterized by its three embracing chambers in the final whorl and wall coarsely agglutinated with smoothly finished surface. It was originally recorded from the Paleocene-Eocene of the Carpathians and later in Spain, Angola, N. Atlantic, Gulf of Mexico and Caribbean, Mediterranean, Australia and N. Pacific. It also occurs in Paleocene rocks of J. Mundassa for the first time in UAE.

Subfamily Recurvoidinae Alekseychik-Mitskevich, 1973

Genus Recurvoides Earland, 1934

Type species Recurvoides contortus Earland, 1934

Recurvoides anormis Mjatliuk, 1970

(Fig. 4.10)

1970 Recurvoides anormis Mjatliuk, p. 84, pl. 18, fig. 4, pl. 19, figs. 1-4. 
2005 Recurvoides anormis; Kaminski \& Gradstein, p. 403, text-fig. 95, pl. 95, figs. 1-7.

2013 Recurvoides anormis; Bindiu et al., p. 123, fig. 5. $8,9$.

Recurvoides anormis is characterized by its subglobular, streptospirally and enrolled test of 6-8 chambers in the final whorl with depressed sutures. It is recorded from lower Maastrichtian-upper Eocene, from the Carpathians, Europe and Trinidad. It is also present in the Danian rocks of J. Mundassa.

Suborder SPIROPLECTAMMININA Mikhalevich, 1992

Superfamily SPIROPLECTAMMINACEA Cushman, 1927

Family Spiroplectamminidae Cushman, 1927

Subfamily Spiroplectammininae Cushman, 1927

Genus Spiroplectinella Kisel'man, 1972

Type species Spiroplecta wrightii Silvestri, 1903

Spiroplectinella dentata (Alth, 1850)

(Fig. 4.11)

1850 Textularia dentata Alth, p. 262, pl. 13, fig. 13. 1968 Spiroplectammina dentata; Neagu, p. 228, testfig. 2. 20.

1972 Semivulvulina dentata; Hanzlíková, p. 49, pl. 9 , fig. 6.

1978 Spiroplectammina dentata; Proto Decima \& Bolli, 1978, p. 796, pl. 1, fig. 4.

1981 Spiroplectammina dentata; Morgiel \& Olszewska, p. 14, pl. pl. 4, fig. 4.

1985 Spiroplectammina dentata; Luger, p. 76, pl. 3, fig. 1.

1993a Spiroplectammina dentata; Anan, p. 314, pl. 1, fig. 3 .

1994 Spiroplectinella dentata; Bolli et al., p. 83, fig. 22. 4-7.

2005b Spiroplectinella dentata; Anan, p. 80.

2005 Spiroplectinella dentata; Kaminski \& Gradstein, p. 349 , text-fig. 106, pl. 106, figs. 1-8.

2013 Spiroplectinella dentata; Bindiu et al., p. 123, fig. 5. 5, 6 .

This Maastrichtian to Paleocene cosmopolitan species was recorded in many Tethyan localities: Trinidad, USA, Netherlands, Poland, Czech, Romania, South Atlantic Ocean, Tunisia, Egypt, UAE. It is also found in the Paleocene rocks of J. Mundassa.

Spiroplectinella subhaeringensis (Grzybowski, 1896)

(Fig. 4.12)
1896 Textularia subhaeringensis Grzybowski, p. 285, pl. 9, figs. 13, 16.

1983 Spiroplectinella subhaeringensis; Tjalsma \& Lohmann, p. 20, pl. 2, fig. 3.

1996 Spiroplectammina subhaeringensis; Kuhnt \& Collins, p. 214, pl. 2, fig. 12.

2005 Spiroplectinella subhaeringensis; Kaminski \& Gradstein, p. 444, text-fig. 108-1, pl. 108, figs. 1-5.

Tjalsma \& Lohmann (1983) noted that the stratigraphic range of this species is Paleocene, and it is rare and patchy in distribution. It is found in the Paleocene rocks of $\mathrm{J}$. Mundassa.

Suborder TROCHAMMININA Saidova, 1981

Superfamily TROCHAMMINACEA Schwager, 1877

Family Trochamminidae Schwager, 1877

Subfamily Trochammininae Schwager, 1877

Genus Trochammina Parker \& Jones, 1859

Type species Nautilus inflatus Montagu, 1808

Trochammina globigeriniformis (Parker \& Jones, 1865) (Fig. 4.13)

1865 Lituola globigeriniformis Parker \& Jones, p. 407, pl. 15, figs. 46, 47.

1946 Trochammina globigeriniformis; Cushman, p. 51, pl. 15, figs. 8, 10, 11 .

1976 Trochammina globigeriniformis; Aubert \& Berggren, p. 411, pl. 1, fig. 17.

1988 Trochammina globigeriniformis; Anan \& Sharabi, p. 202 , pl. 1, fig. 8 .

This species has a trochospiral test, chambers increasing gradually as added with a coarsely finished surface. It occurs in Maastrichtian-Paleocene rocks at some localities: USA, Tunisia, Egypt, Poland. It is also recorded for the first time in UAE from the Paleocene rocks of J. Mundassa.

Suborder VERNEUILININA Mikhalevich \& Kaminski, 2004

Superfamily VERNEUILINACEA Cushman 1911

Family Verneuilinoididae Cushman 1911

Subfamily Verneuilinoidinae Suleymanov, 1973

Genus Gaudryinopsis Podobina, 1975

Type species Gaudryina vulgaris Kipriyanova, 1960

Gaudryinopsis vulgaris Kipriyanova, 1960

(Fig. 4.14) 


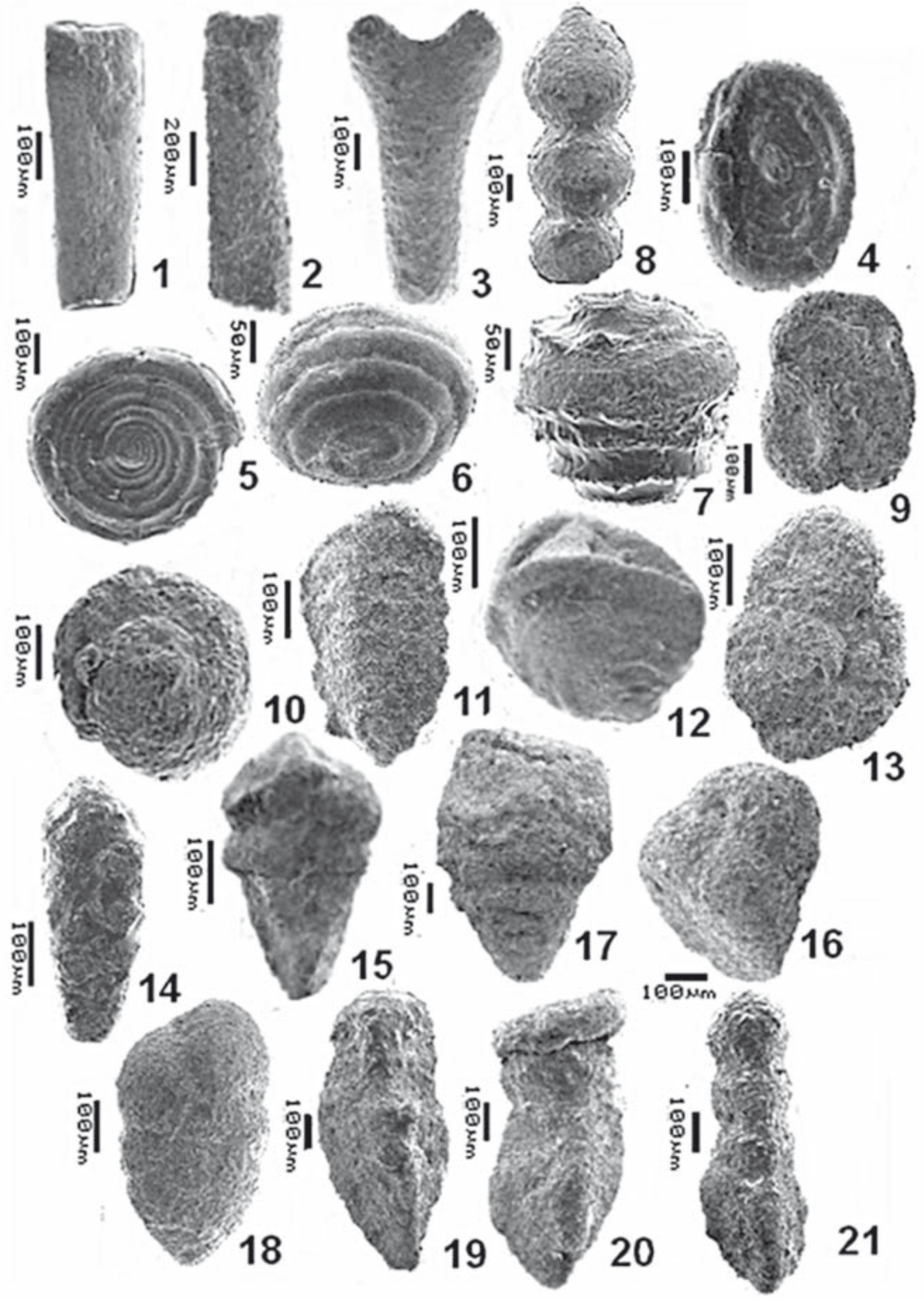


1960 Gaudryina vulgaris Kipriyanova, p. 78.

1987 Gaudryinopsis vulgaris; Loeblich \& Tappan, p. 133 , pl. 140, figs. 26-32.

The genus Gaudryinopsis differs from Gaudryina by its inflated subglobular chambers and rounded section. Gaudryinopsis vulgaris has an elongate test, with a short early triserial stage, later biserial and commonly with nearly parallel sides, chambers subglobular to slightly appressed, sutures depressed, test rounded to ovoid in section, wall finely agglutinated. This Triassic to Eocene species is recorded for the first time in the Danian rocks of J. Mundassa.

Superfamily VERNEUILINACEA Cushman, 1911

Family Verneuilinidae Cushman, 1911

Subfamily Verneuilininae Cushman, 1911

Genus Gaudryina d'Orbigny, 1839

Type species Gaudryina rugosa d'Orbigny, 1839

Gaudryina pyramidata Cushman, 1926

1926 Gaudryina laevigata Franke var. pyramidata Cushman, p. 587, pl. 16, fig. 8.

1956 Gaudryina pyramidata; Said \& Kenawy, p. 124, pl. 1, fig. 26.

1978 Spiroplectammina dentata; Proto Decima \& Bolli, 1978, p. 793, pl. 1, fig. 6 .

1983 Gaudryina pyramidata; Tjalsma \& Lohmann, p. 12, pl. 2, fig. 4., pl. 8, fig. 1 .

1993 Gaudryina pyramidata; Hewaidy \& Al-Hitmi, p. 478 , pl. 4 , fig. 8 .

1994 Gaudryina pyramidata; Bolli et al., p. 90, fig. 24. 4-6.

2005 Gaudryina pyramidata; Sztrákos, p. 184, pl. 2, fig. 5 .

2005b Gaudryina pyramidata; Anan, p. 81, pl. 1, fig. 4.

2012 Gaudryina pyramidata; Anan, p. 64, pl. 1, figs. 8,9 .
This cosmopolitan species was recorded from the Maastrichtian Velasco Shale in Mexico, Trinidad and California, and later from the Paleocene rocks in some localities in the Tethys (i.e., Atlantic Ocean, Spain, France, Italy, Tunisia, Egypt, Qatar, UAE) as well as from Paleocene rocks of J. Mundassa. Anan (2012) considered that cosmopolitan Maastrichtian-Paleocene species $G$. pyramidata has an evolutionary development to the two Early Eocene G. speijeri and G. ameeri (both described by Anan, 2012), from the G. pyramidata-G. speijeri lineage on one hand, as well as the G. pyramidata-G. ameer $i$ lineage on the other.

\section{Gaudryina rugosa d'Orbigny, 1840}

(Fig. 4.15)

1840 Gaudryina rugosa d'Orbigny, p. 44, pl. 4, figs. 20, 21.

1993a Gaudryina rugosa; Anan, p. 314, pl. 1, fig. 6.

2001 Gaudryina rugosa; Hewaidy \& Strougo, p. 15, pl. 1, fig. 9 .

2005b Gaudryina rugosa; Anan, p. 82.

The species was recorded from the Paleocene rocks from Egypt, and later in UAE. It is also found in the Paleocene rocks of J. Mundassa.

Genus Verneuilina d'Orbigny, 1839

Type species Verneuilina tricarinata d'Orbigny, 1839

Verneuilina aegyptiaca Said \& Kenawy, 1956

1956 Verneuilina aegyptiaca Said \& Kenawy, p. 122, pl. 1, fig. 16.

1993b Verneuilina aegyptiaca; Anan, p. 656, pl. 2, fig. 2. 1994 Gaudryina pyramidata; Speijer, p. 44, pl. 4, fig. 1. 2004 Verneuilina aegyptiaca; Anan, p. 41, pl. 1, fig. 1.

The species was originally recorded from Maastrichtian to Paleocene rocks from Egypt. It is also found in

Figure 4. 1) Bathysiphon eocenicus Cushman \& Hanna, 1927; Sample 15, 2) Bathysiphon paleocenicus El-Dawy, 2001; S. 6, Danian (P1c), 3) Nothia excelsa (Grzybowski, 1898); S. 3, Danian (P1b), 4) Ammodiscus angustus (Friedberg, 1901); S. 11, Selandian (P3), 5) Ammodiscus cretaceus (Reuss, 1845); S. 13, Selandian (P3), 6) Glomospira gordialis (Jones \& Parker, 1860); S. 12, Selandian (P3), 7) Repmanina sp.; S. 10, Selandian (P3), 8) Psammolingulina sp., S. 3, Danian (P1b), 9) Ammosphaeroidina pseudopauciloculata (Mjatliuk, 1966); S. 6, Danian (P1c), 10) Recurvoides anormis Mjatliuk, 1970; S. 7, Danian (P2), 11) Spiroplectinella dentata (Alth, 1850); S. 12, Selandian (P3), 12) Spiroplectinella subhaeringensis (Grzybowski, 1896); S. 14, Selandian (P3), 13) Trochammina globigeriniformis (Parker \& Jones, 1865); S. 10, Selandian (P3), 14) Gaudryinopsis vulgaris Kipriyanova, 1960; S. 5, Danian (P1c), 15) Gaudryina rugosa d'Orbigny, 1840; S. 15, Selandian (P3), 16) Verneuilina paleocenica (Tjalsma \& Lohmann, 1983); S. 5, Danian (P1c), 17) Remesella varians (Glaessner, 1937); S. 10, Selandian (P3), 18) Dorothia pupa (Reuss, 1860); S. 10, Selandian (P3), 19) Clavulinoides concavus (Cushman, 1931); S. 14, Selandian (P3), 20) Pseudoclavulina farafraensis LeRoy, 1953; S. 13, Selandian (P3), 21) Pseudoclavulina hewaidyi Anan, 2008; S. 3, Danian (P1b). 
Maastrichtian rocks of Tunisia and Paleocene rocks of J. Malaqet (UAE). It occurs in Paleocene rocks in J. Mundassa (this study). Anan (2004) presented some phylogenetic lineages in the Maastrichtian to Eocene transition of Egypt, one of which is the Verneuilina aegyptiaca $-V$. luxorensis lineage.

Verneuilina paleocenica (Tjalsma \& Lohmann, 1983) (Fig. 4.16)

1983 Tritaxia paleocenica Tjalsma \& Lohmann, p. 21, pl. 1, figs. 6-8, text-fig. 18 .

This species was originally recorded from Paleocene sediments of the Rio Grande Rise in the South Atlantic. It belongs here to the genus Verneuilina due to its triserial test and triangular cross section as noted by Tjalsma \& Lohmann (1983), not triserial to uniserial as in the genus Tritaxia. Tjalsma \& Lohmann (op. cit.) added that in fully developed individuals the chambers are sometimes uniserial arranged. In the Paleocene rocks from J. Mundassa, this species has a triserial chamber arrangement as originally described. It is recorded here for the first time from UAE and Arabia, and may be outside also the original record.

Suborder ATAXOPHRAGMIINA Fursenko, 1958

Superfamily ATAXOPHRAGMIACEA Schwager, 1877

Family Ataxophragmiidae Schwager, 1877

Subfamily Liebusellinae Saidova, 1981

Genus Remesella Vašíček, 1947

Type species Remesella mariae Vašíček, 1947 =

Textulariella? varians Glaessner, 1937

Remesella varians (Glaessner, 1937)

(Fig. 4.17)

1937 Textulariella? varians Glaessner, p. 366-367, pl. 2, fig. 15.

1988 Matanzia varians; Kaminski et al., p. 196, pl. 9, fig. 14, pl. 10, fig. 14 .

1996 Remesella varians; Kuhnt \& Collins, p. 213, pl. 2, fig. 1 .

1996 Pseudotextulariella cretosa; Anan, p. 150, fig. 3. 8 .

2004 Remesella varians; Galeotti et al., p. 96, pl. 4, fig. 14.

The species is characterized by its conical test, triserial to biserial arrangement with low basal aperture, finally agglutinated wall. It was recorded from the upper Cretaceous in Europe, and later from Trinidad and
UAE. It is recorded here from the Paleocene rocks of J. Mundassa.

Family Eggerellidae Cushman, 1937

Subfamily Dorothiinae Balakhmatova, 1972

Genus Dorothia Plummer, 1931

Type species Dorothia bulletta Carsey, 1926

Dorothia bulletta (Carsey, 1926)

1926 Gaudryina bulletta Carsey, p. 28, pl. 4, fig. 4. 1956 Dorothia bulletta; Haque, p. 51, pl. 3, fig. 5. 1985 Dorothia bulletta; Luger, p. 78, pl. 3, fig. 12. 1993a Dorothia bulletta; Anan, p. 314, pl. 1, fig. 10. 2005 Dorothia bulletta; Sztrákos, p. 200, pl. 2, fig. 8.

This species was observed from the Maastrichtian to Lower Eocene rocks in many parts of the Tethys: USA, France, Egypt, UAE, Qatar, Pakistan. It is recorded here from the Paleocene of J. Mundassa.

Dorothia pupa (Reuss, 1860)

(Fig. 4.18)

1860 Textilaria pupa Reuss, p. 232, pl. 13, figs. 4, 5. 1953 Dorothia pupa; LeRoy, p. 28, pl. 1, figs. 14, 15. 1956 Dorothia pupa; Said \& Kenawy, p. 128, pl. 1, fig. 53.

1993a Dorothia pupa; Anan, p. 314, pl. 1, fig. 12.

This species is characterized by having trochospirally enrolled early stage and a small number of inflated biserial chambers in the last stage with fine finished surface. It was recorded from the Maastrichtian-Lower Eocene rocks in some parts of the Tethys (i.e., USA, Europe, Egypt, UAE). It is presented here from the Paleocene succession of $\mathrm{J}$. Mundassa.

Genus Marssonella Cushman, 1930

Type species Gaudryina oxycona Reuss, 1860

Marssonella oxycona (Reuss, 1860)

1860 Gaudryina oxycona Reuss, p. 229, pl. 12, fig. 3. 1953 Marssonella oxycona; LeRoy, p. 39, pl. 1, figs. 3, 4.

1956 Marssonella oxycona; Haque, p. 51, pl. 3, fig. 4. 1993 Marssonella oxycona; Hewaidy \& Al-Hitmi, p. 479 , pl. 5 , figs. 8,9 .

1994 Marssonella oxycona; Bolli et al., p. 94, fig. 25. 5,6 .

2005b Marssonella oxycona; Anan, pl. 1, fig. 8. 
This species was found in Maastrichtian to Lower Eocene rocks in many parts of the Tethys: USA, Caribbean region, France, Egypt, UAE, Qatar, Pakistan. It occurs in the Paleocene rocks of J. Mundassa.

Family Pseudogaudryinidae Loeblich \& Tappan, 1985

Subfamily Pseudogaudryininae Loeblich \& Tappan, 1985

Genus Clavulinoides Cushman, 1936

Type species Clavulina trilatera Cushman, 1926

Clavulinoides concavus (Cushman, 1931)

(Fig. 4.19)

1931 Clavulina trilatera Cushman var. concava Cushman, p. 302, pl. 34, fig. 12.

1946 Clavulina trilatera Cushman var. concava; Cushman, p. 38, pl. 9, fig. 18.

1956 Clavulinoides trilatera concavus; Said \& Kenawy, p. 126 , pl. 1, fig. 40 .

1988 Clavulinoides trilatera; Weidich, p. 350, pl. 3, figs. $13,14,17$.

2011 Clavulinoides concavus; Anan, p. 298, pl. 1, fig. 2.

Clavulinoides concavus was originally recorded from the Upper Cretaceous of Texas (USA), and later from the Maastrichtian to Paleocene in Egypt and UAE. Weidich (1988) noted that Clavulinoides trilatera is perhaps one of the most variable "Clavulina" species and there are intermediate forms at least between seven species, subspecies and varieties: $C$. trilatera, $C$. trilatera concava, C. trilatera aspera, C. aspera whitei, C. compressa, $C$. insings, C. plummerae. Specimens with concave sides are the extreme variants on one end, while thin concave-convex types from the other end. The figured specimen from UAE has concave sides, acute periphery and triangular cross section. It is recorded here from the Paleocene of J. Mundassa, for first time in UAE.

Genus Pseudoclavulina Cushman, 1936

Type species Clavulina clavata Cushman, 1926

Pseudoclavulina farafraensis LeRoy, 1953

(Fig. 4.20)

1953 Pseudoclavulina farafraensis LeRoy, p. 44, pl. 2, fig. 9 .

1993a Pseudoclavulina farafraensis; Anan, p. 314, pl. 1, fig. 10.

1993 Pseudoclavulina farafraensis; Hewaidy \& AlHitmi, p. 481, pl. 6, figs. 5, 6 .
1995 Pseudoclavulina farafraensis; Nomura \& Brohi, p. 227, pl. 1, fig. 19.

2002 Pseudoclavulina farafraensis; Al-Hitmi, p. 45, pl. 1, fig.13.

2005b Pseudoclavulina farafraensis; Anan, p. 87, pl. 1, fig. 10.

The species was recorded in all Egyptian Upper Cretaceous rocks, as well as in some localities in the Tethys: Egypt, Pakistan, Qatar and UAE. It is documented here from the Paleocene of J. Mundassa.

\section{Pseudoclavulina hewaidyi Anan, 2008}

(Fig. 4.21)

2008 Pseudoclavulina hewaidyi Anan, p. 248, pl. 1, fig. 1.

This species was originally recorded from the Paleocene rocks of Sinai, Egypt. It is characterized by its large triserial early stage and discoidal chambers in the uniserial later stage with depressed sutures. It is observed in the Paleocene of J. Mundassa, for the first time in UAE and Arabia.

\section{TEMPORAL DISTRIBUTION OF THE PALEOCENE SPECIES}

Table 1 shows the identified twenty-six agglutinated foraminiferal species in the Paleocene succession of $\mathrm{J}$. Mundassa, UAE. The recorded species of J. Malaqet and Qarn El Barr sections was observed by Anan (1993a, b, respectively) as well as some other chronological horizon in some localities of the Tethys: Egypt (LeRoy, 1953; Said \& Kenawy, 1956; Luger, 1985; Anan \& Sharabi, 1988; Speijer, 1994; El-Dawy, 2001; Anan, 2004, 2005a, b, 2008, 2011), Tunisia (Aubert \& Berggren, 1976; Speijer, 1994; Saint-Marc \& Berggren, 1988), Spain (Kuhnt \& Kaminski, 1993), France (Sztrákos, 2005), Italy (Proto Decima \& De Biase, 1975), Trinidad (Bolli et al., 1994), Atlantic Ocean (Cushman, 1946; Berggren, 1974; Tjalsma \& Lohmann, 1983), Japan \& New Zealand (Kaiho, 1988). The following remarks can be presented:

1. The Paleocene succession of J. Mundassa yields 26 agglutinated species compared with 16 species from $\mathrm{J}$. Malaqet, 12 species from Qarn El Barr, and the total of UAE are 35 species.

2. The Paleocene from Egypt yields 35 agglutinated species compared with 16 species from Tunisia, 13 species from France, 8 species from Spain, 5 species from Italy, 14 species from Trinidad, 5 species from the Atlantic Ocean, and only 3 species from Japan \& New Zealand. 
Table 1. Paleogeographic distribution of the Paleocene agglutinated benthic foraminifera in the United Arab Emirates $=\mathrm{UAE}(\mathrm{MN}$ $=$ Mundassa, $\mathrm{MQ}=$ Malaqet, $\mathrm{QB}=$ Qarn El Barr sections) and some other Tethyan localities $(\mathrm{E}=\mathrm{Egypt}, \mathrm{T}=\mathrm{Tunisia}, \mathrm{F}$ $=$ France, $\mathrm{S}=$ Spain, $\mathrm{I}=$ Italy, $\mathrm{D}=$ Trinidad, $\mathrm{AO}=$ Atlantic Ocean, $\mathrm{JZ}=$ Japan and New Zealand). Note: $\mathrm{x}=$ recorded species, - = not recorded.

\begin{tabular}{|c|c|c|c|c|c|c|c|c|c|c|c|c|c|c|}
\hline \multirow{2}{*}{ Sp. No. } & \multirow{2}{*}{\multicolumn{2}{|c|}{$\begin{array}{l}\text { Paleocene agglutinated } \\
\text { Benthic foraminiferal species }\end{array}$}} & \multicolumn{4}{|c|}{ United Arab Emirates } & \multicolumn{8}{|c|}{ Some Tethyan localities } \\
\hline & & & $\mathrm{MN}$ & MQ & QB & UAE & $\mathrm{E}$ & $\mathrm{T}$ & $\mathrm{F}$ & $\mathrm{S}$ & I & $\mathrm{D}$ & $\mathrm{AO}$ & $\mathrm{JZ}$ \\
\hline 1 & Bathysiphon & arenaceous & - & $\mathrm{x}$ & $\mathrm{x}$ & $\mathrm{x}$ & $\mathrm{x}$ & $\mathrm{x}$ & - & $\mathrm{x}$ & - & - & - & - \\
\hline 2 & & eocenicus & $\mathrm{x}$ & - & - & $\mathrm{x}$ & - & - & - & - & - & $\mathrm{x}$ & - & - \\
\hline 3 & & Paleocenicus & $\mathrm{x}$ & - & - & $\mathrm{x}$ & $\mathrm{x}$ & - & - & - & - & - & - & - \\
\hline 4 & Nothia & excelsa & $\mathrm{x}$ & - & - & $\mathrm{x}$ & - & - & - & $\mathrm{x}$ & - & $\mathrm{x}$ & - & - \\
\hline 5 & Ammodiscus & angustus & $\mathrm{x}$ & - & - & $\mathrm{x}$ & - & - & - & - & - & - & - & - \\
\hline 6 & & cretaceus & $\mathrm{x}$ & $\mathrm{x}$ & $\mathrm{x}$ & $\mathrm{x}$ & $\mathrm{x}$ & $\mathrm{x}$ & $\mathrm{x}$ & - & - & - & - & $\mathrm{x}$ \\
\hline 7 & Glomospira & gordialis & $\mathrm{x}$ & $\mathrm{x}$ & - & $\mathrm{x}$ & $\mathrm{x}$ & $\mathrm{x}$ & $\mathrm{x}$ & $\mathrm{x}$ & - & $\mathrm{x}$ & - & - \\
\hline 8 & Repmanina & sp. & $\mathrm{x}$ & - & - & $\mathrm{x}$ & - & - & - & - & - & - & - & - \\
\hline 9 & Psammolingulina & sp. & $\mathrm{x}$ & - & - & $\mathrm{x}$ & - & - & - & - & - & - & - & - \\
\hline 10 & Ammobaculites & khargaensis & - & - & - & - & $\mathrm{x}$ & - & - & - & - & - & - & - \\
\hline 11 & & schwageri & $\mathrm{x}$ & - & - & $\mathrm{x}$ & - & - & - & - & - & - & - & - \\
\hline 12 & $\begin{array}{l}\text { Ammosphaer- } \\
\text { oidina }\end{array}$ & pseudopauciloculata & $\mathrm{x}$ & - & - & $\mathrm{x}$ & - & - & $\mathrm{x}$ & $\mathrm{x}$ & - & $\mathrm{x}$ & - & - \\
\hline 13 & Recurvoides & anormis & $\mathrm{x}$ & - & - & $\mathrm{x}$ & - & - & - & - & - & - & - & - \\
\hline 14 & Spiroplectinella & dentata & $\mathrm{x}$ & $\mathrm{x}$ & - & $\mathrm{x}$ & $\mathrm{x}$ & $\mathrm{x}$ & $\mathrm{x}$ & $\mathrm{x}$ & $\mathrm{x}$ & $\mathrm{x}$ & - & - \\
\hline 15 & & esnaensis & - & - & - & - & $\mathrm{x}$ & $\mathrm{x}$ & $\mathrm{x}$ & - & - & - & - & - \\
\hline 16 & & spectabilis & - & - & - & - & $\mathrm{x}$ & $\mathrm{x}$ & $\mathrm{x}$ & - & - & $\mathrm{x}$ & $\mathrm{x}$ & $\mathrm{x}$ \\
\hline 17 & & subhaeringensis & $\mathrm{x}$ & - & - & $\mathrm{x}$ & $\mathrm{x}$ & - & $\mathrm{x}$ & - & - & - & $\mathrm{x}$ & - \\
\hline 18 & Vulvulina & colei & - & $\mathrm{x}$ & - & $\mathrm{x}$ & $\mathrm{x}$ & - & - & - & - & $\mathrm{x}$ & $\mathrm{x}$ & - \\
\hline 19 & Trochammina & globigeriniformis & $\mathrm{x}$ & - & - & $\mathrm{x}$ & - & $\mathrm{x}$ & - & - & - & - & - & - \\
\hline 20 & Plectina & chapmani & - & - & - & - & $\mathrm{x}$ & - & - & - & - & - & - & - \\
\hline 21 & Gaudryinopsis & vulgaris & $\mathrm{x}$ & - & - & $\mathrm{x}$ & - & - & - & - & - & - & - & - \\
\hline 22 & Gaudryina & aissana & - & - & - & - & - & $\mathrm{x}$ & - & - & - & - & - & - \\
\hline 23 & & elegantissima & - & - & $\mathrm{x}$ & $\mathrm{x}$ & $\mathrm{x}$ & - & - & - & - & - & - & - \\
\hline 24 & & laevigata & - & - & $\mathrm{x}$ & $\mathrm{x}$ & $\mathrm{x}$ & - & - & - & - & $\mathrm{x}$ & - & - \\
\hline 25 & & limbata & - & $\mathrm{x}$ & - & $\mathrm{x}$ & $\mathrm{x}$ & - & - & - & - & - & - & - \\
\hline 26 & & nekhlensis & - & - & - & - & $\mathrm{x}$ & - & - & - & - & - & - & - \\
\hline 27 & & pyramidata & $\mathrm{x}$ & - & $\mathrm{x}$ & $\mathrm{x}$ & $\mathrm{x}$ & $\mathrm{x}$ & $\mathrm{x}$ & $\mathrm{x}$ & $\mathrm{x}$ & $\mathrm{x}$ & $\mathrm{x}$ & - \\
\hline 28 & & rectiangula & - & - & - & - & - & $\mathrm{x}$ & - & - & - & - & - & - \\
\hline 29 & & rugosa & $\mathrm{x}$ & $\mathrm{x}$ & $\mathrm{x}$ & $\mathrm{x}$ & $\mathrm{x}$ & - & $\mathrm{x}$ & - & - & $\mathrm{x}$ & - & - \\
\hline 30 & Verneuilina & aegyptiaca & $\mathrm{x}$ & - & $\mathrm{x}$ & $\mathrm{x}$ & $\mathrm{x}$ & - & - & - & - & - & - & - \\
\hline 31 & & cretacea & - & $\mathrm{x}$ & - & $\mathrm{x}$ & $\mathrm{x}$ & - & - & - & - & - & - & - \\
\hline 32 & & karreri & - & - & - & - & $\mathrm{x}$ & - & - & - & - & - & - & - \\
\hline 33 & & paleocenicus & $\mathrm{x}$ & - & - & $\mathrm{x}$ & - & - & - & - & - & - & - & - \\
\hline 34 & Arenobulimina & aegyptiaca & - & $\mathrm{x}$ & $\mathrm{x}$ & $\mathrm{x}$ & $\mathrm{x}$ & - & - & - & - & - & - & - \\
\hline
\end{tabular}




\begin{tabular}{|c|c|c|c|c|c|c|c|c|c|c|c|c|c|c|}
\hline 35 & Remesella & varians & $\mathrm{x}$ & $\mathrm{x}$ & - & $\mathrm{x}$ & - & - & $\mathrm{x}$ & $\mathrm{x}$ & $\mathrm{x}$ & $\mathrm{x}$ & - & - \\
\hline 36 & Dorothia & bulletta & $\mathbf{x}$ & $\mathrm{x}$ & $\mathrm{x}$ & $\mathrm{x}$ & $\mathrm{x}$ & - & $\mathrm{x}$ & - & - & - & - & - \\
\hline 37 & & concinna & - & - & - & - & $\mathrm{x}$ & - & - & - & - & - & - & - \\
\hline 38 & & identata & - & - & - & - & - & $\mathrm{x}$ & - & - & $\mathrm{x}$ & - & - & - \\
\hline 39 & & plummerae & - & - & - & - & - & $\mathrm{x}$ & - & - & - & - & - & - \\
\hline 40 & & pontoni & - & - & - & - & $\mathrm{x}$ & - & - & - & - & - & - & - \\
\hline 41 & & pupa & $\mathrm{x}$ & $\mathrm{x}$ & - & $\mathrm{x}$ & $\mathrm{x}$ & - & - & - & - & $\mathrm{x}$ & - & - \\
\hline 42 & & sinaensis & - & - & - & - & $\mathrm{x}$ & - & - & - & - & - & - & - \\
\hline 43 & Marssonella & ellisorae & - & - & - & - & $\mathrm{x}$ & - & - & - & - & - & - & - \\
\hline 44 & & oxycona & $\mathrm{x}$ & $\mathrm{x}$ & $\mathrm{x}$ & $\mathrm{x}$ & $\mathrm{x}$ & $\mathrm{x}$ & $\mathrm{x}$ & $\mathrm{x}$ & - & $\mathrm{x}$ & - & - \\
\hline 45 & Clavulinoides & concavus & $\mathrm{x}$ & - & - & $\mathrm{x}$ & - & - & - & - & - & - & - & - \\
\hline 46 & & trilaterus & - & - & - & - & $\mathrm{x}$ & $\mathrm{x}$ & - & - & $\mathrm{x}$ & $\mathrm{x}$ & - & - \\
\hline 47 & Pseudoclavulina & farafraensis & $\mathrm{x}$ & $\mathrm{x}$ & $\mathrm{x}$ & $\mathrm{x}$ & $\mathrm{x}$ & - & - & - & - & - & - & - \\
\hline 48 & & maqfiensis & - & - & - & - & $\mathrm{x}$ & $\mathrm{x}$ & - & - & - & - & - & - \\
\hline 49 & & midwayensis & - & - & $\mathrm{x}$ & $\mathrm{x}$ & $\mathrm{x}$ & $\mathrm{x}$ & - & - & - & - & - & - \\
\hline 50 & & hewaidyi & $\mathrm{x}$ & $\mathrm{x}$ & - & $\mathrm{x}$ & $\mathrm{x}$ & - & - & - & - & - & - & - \\
\hline 51 & Textularia & nilotica & - & $\mathrm{x}$ & - & $\mathrm{x}$ & $\mathrm{x}$ & - & - & - & - & - & - & - \\
\hline 52 & & farafraensis & - & - & - & - & $\mathrm{x}$ & - & $\mathrm{x}$ & - & - & - & $\mathrm{x}$ & - \\
\hline 53 & & plummerae & - & - & - & - & - & - & - & - & $\mathrm{x}$ & - & - & $\mathrm{x}$ \\
\hline
\end{tabular}

3. The close resemblance of the Paleocene benthic foraminifera of J. Malaqet (UAE) with the synchronous age from the Sinai (Egypt) shows the most probably were parts of the same palaeogeographic province at that time. Moreover, a middle to outer neritic environmental deposition (Midway-Type Fauna, about 50-200 m water depth) is suggested for the Paleocene time (Anan, 1993a).

4. The unclosed number of Paleocene agglutinated species between the different localities in the Tethys may due to the lack of detailed study for those localities, to different latitudes, to differences in palaeoenvironmental conditions (depth, salinity, nutrients, dissolved oxygen, land barriers).

5. Some species are recorded at four or more localities: Bathysiphon arenaceous, Ammodiscus cretaceous, Glomospira gordialis, Ammosphaeroidina pseudopauciloculata, Spiroplectinella dentata, S. spectabilis, S. subhaeringensis, Vulvulina colei, Gaudryina pyramidata, G. rugosa, Marssonella oxycona. This record emphasizes the extended realms of Tethys, Indo-Pacific with Atlantic during the Paleocene.

\section{PALAEOGEOGRAPHY}

Paleogene palaeogeographic maps (partly or regionally) were used by many authors (i.e., Phillips, 1971; Berggren, 1978; Zachos et al., 1993; Rosenbaum et al., 2002) show that the Tethyan realm had been connected with the IndoPacific Ocean from the east and the Atlantic Ocean to the west. Some other studies can be added:

1. Berggren (1971) suggested that during the Paleogene, the fauna of the Mediterranean and the Indo-Pacific exhibit pronounced similarities, which indicate that the connection between the two areas was mentioned by a marine seaway, and the East Atlantic fauna was much more closely related to the fauna than it is today. In the western Atlantic a narrow connection between it and Pacific existed. In the early Tertiary, a large east-west Tethyan sea extended from the Indian Ocean in the east to the Atlantic Ocean in the west, and in the western Atlantic a narrow connection between it and the Pacific existed.

2. Moore et al. (1978) noted the extended realms of Tethys, Indo-Pacific with Atlantic during the Paleogene.

3. Adams et al. (1983) noted that the continuous marine Paleogene connection between the area occupied by the present-day Mediterranean and the Indian Ocean had been lost by mid Burdigalian (early Miocene) times when a land bridge connected S.W. Asia to Arabia, which means that the faunas of the Mediterranean and Indo-West Pacific began to diverge. They also added that the final disconnection must have been caused by a general elevation of this region rather than by a global eustatic change.

4. Anan (1995) concluded that the Tethyan realm during the Eocene extends to the southeast and connected with the Indo-Pacific realm via the seaway separating Arabia from the Iran-India region. 
5. Haynes \& Nwabufo-Ene (1998) suggested wider Tethyan connections, as far as the Carpathians and Pakistan.

6. Rögl (1999) noted that by the end of the Eocene the Tethys Ocean had already vanished, a new Indian Ocean was born, the western end of the Tethys was reduced to a Mediterranean Sea, Europe was still an archipelago and intercontinental seas covered large areas of the European platform and of western Asia. He also noted that between the stable Eurasian platform and the relics of the western Tethys, elongate deep basins had formed and north of India a marine connection stretched to the West Pacific. It means that the western end of the relic Tethys connected the Indo-Pacific and the Atlantic Ocean.

7. Meulenkamp \& Sissingh (2003) noted that the Arabian Platform was still largely covered by the sea in Paleocene, but was subject to a major regression in the Middle to Late Eocene.

\section{CONCLUSIONS}

1. Jabal Mundassa is considered the only outcrop in the Al Ain area (UAE) that has Danian sediments (samples 1-9, about $10 \mathrm{~m}$ thick), and presented the most complete Danian section studied so far in the UAE.

2. Twenty-six agglutinated benthic foraminiferal species belonging to nineteen genera are recorded from J. Mundassa section. These are: Bathysiphon eocenicus, B. paleocenicus, Dendrophrya excelsa, Ammodiscus angustus, A. cretaceus, Glomospira gordialis, Repmanina sp., Psammolingulina sp., Ammobaculites schwageri, Ammosphaeroidina pseudopauciloculata, Recurvoides anormis, Spiroplectinella dentata, S. subhaeringensis, Trochammina globigeriniformis, Gaudryinopsis vulgaris, Gaudryina pyramidata, G. rugosa, Verneuilina aegyptiaca, V. paleocenica, Remesella varians, Dorothia bulletta, D. pupa, Marssonella oxycona, Clavulinoides concavus, Pseudoclavulina farafrensis and Pseudoclavulina hewaidyi. One of these illustrated species Psammolingulina $s p$. is the oldest known occurrence of the genus and is likely to be new.

3. The K/P boundary in the J. Mundassa section formed by an unconformity, and the missing horizon includes the two early Danian biozones: G. cretacea (P0) and P. eugubina $(\mathrm{Pa})$. Development at the unconformity is most probably controlled by active tectonic, mainly synsedimentary faulting, and eustatic sea-level changes, which represents a major, but short-lived regression at J. Mundassa, at the end of the Cretaceous (Vail et al., 1977 and Haq et al., 1987).

4. After the close of the Danian, a rapid tectonic subsidence took place. The Cenozoic history of the Arabian Gulf began with a regression at the K/P boundary, which left most of the Arabia emergent with the exception of the basinal areas in the northern UAE (i.e., at Ras Al Khaima basin). The J. Mundassa basin is the other basin in the eastern UAE that remained marine. This event followed by a rapid transgression that submerged the $\mathrm{Al}$ Ain area; in particular Selandian sediments ( $M$. angulata Zone) were deposited at both J. Mundassa and J. Malaqet, as well as at the Qarn El Barr sections.

5. In the J. Mundassa section, the $\mathrm{D} / \mathrm{S}$ transition is neither a marked black shale bed as in Egypt, nor the "NeOduwi event" of Speijer (2003) as in Tunisia.

\section{ACKNOWLEDGEMENTS}

The author would like to express his sincere appreciation to the United Arab Emirates University for facilitating in the photography the foraminifera, to Prof. Michael Kaminski, King Fahd University of Petroleum and Minerals (Saudi Arabia), and Prof. Jeno Nagy, University of Oslo (Norway) for improving the English language of the manuscript and valuable comments.

\section{REFERENCES}

Abdelghany, O. 2003. Late Campanian-Maastrichtian foraminifera from the Simsima Formation on the western side of the Northern Oman Mountains. Cretaceous Research, 24, 391-405.

Adams, C.G., Gentry, A.W. \& Whybrow, P.J. 1983. Dating the terminal Tethys event. Utrecht Micropaleontological Bulletin, 30, 273-298.

Al-Hitmi, H. 2002. Foraminiferal biostratigraphy of the Upper Cretaceous succession in southwest Qatar, Arabian Gulf. Egyptian Journal of Paleontology, 2, 41-54.

Alth, A. 1850. Geognostisch-paläontologische Beschreibung der nächsten Umgebing von Lemberg. Haidinger's naturwissenschaften Abhandlungen, 3, 171-284.

Anan, H.S. 1993a. Paleocene benthonic foraminifera of Jabal Malaqet, Al Ain region, United Arab Emirates. Al-Azhar Bulletin Science Series, 4, 293-320.

Anan, H.S. 1993b. Maastrichtian-Paleocene micropaleontology and biostratigraphy of Qarn El-Barr section, Al Dhayd area, United Arab Emirates. Al-Azhar Bulletin Science Series, 4, 639-670.

Anan, H.S. 1994. Benthic foraminifera around Middle/Upper Eocene boundary in Egypt. Middle East Research Center, Ain Shams University, Earth Science Series, 8, 210-233.

Anan, H.S. 1995. Late Eocene biostratigraphy of Jabals Malaqet and Mundassa of Al Ain region, United Arab Emirates. Revue de Micropaléontologie, 38, 3-14.

Anan, H.S. 1996. Early Eocene foraminifera of Jabal Hafit, United Arab Emirates. Middle East Research Center, Ain Shams University, Earth Science Series, 10, 147-162. 
Anan, H.S. 2004. A lineage phylogeny for some Maastrichtian to Ypresian benthic foraminifera in Egypt. Egyptian Journal of Paleontology, 4, 39-57.

Anan, H.S. 2005a. Agglutinated Middle-Upper Eocene foraminifera in Jabal Hafit, Al Ain area, United Arab Emirates. Revue de Paléobiologie, 24, 17-27.

Anan, H.S. 2005b. Maastrichtian agglutinated foraminifera in Egypt and other Tethyan countries. Egyptian Journal of Paleontology, 5, 75-92.

Anan, H.S. 2007. Taxonomy, paleogeography, paleoecology and paleoclimatology of the Late Eocene benthic foraminifera of Jabal Malaqet, United Arab Emirates, northern Oman Mountains. Egyptian Journal of Paleontology, 7, 67-85.

Anan, H.S. 2008. Latest Maastrichtian Plummerita haggagae and Paleocene Pseudoclavulina hewaidyi, two new foraminiferal species from Egypt. Egyptian Journal of Paleontology, 8, 245-254.

Anan, H.S. 2011. Additional to the Maastrichtian foraminifera of the Middle East. Revue de Paléobiologie, 30, 295-311.

Anan, H.S. 2012. A lineage phylogeny from some CretaceousTertiary agglutinated benthic foraminiferal species in Egypt and Tethys. Egyptian Journal of Paleontology, 12, 59-72.

Anan, H.S., Bahr, S.A., Bassiouni, M.A., Boukhary, M.A. \& Hamdan, A.R. 1992. Contribution to Early EoceneOligocene biostratigraphy of Jabal Hafit succession, United Arab Emirates. Middle East Research Center, Ain Shams University, Earth Science Series, 6, 225-247.

Anan, H.S. \& Hamdan, A.R. 1993. Paleocene planktonic foraminifera of Jabal Malaqet, East of Al Ain, United Arab Emirates. Neues Jahrbuch für Geologie und Paläontologie, H. 1, 27-48.

Anan, H.S. \& Sharabi, S.A. 1988. Benthonic foraminifera from the Upper Cretaceous-Lower tertiary rocks of northwest Kharga Oasis, Egypt. Middle East Research Center, Ain Shams University, Earth Science series, 2, 191-218.

Ansorge, J., Frenzel, P. \& Reich M. 1999. Die Schreibkreide von Quitzin (Vorpommern). Greifswalder Geowissenschaftliche Beitrage, 3 Abb., 6, 225-236.

Aubert, J. \& Berggren, W.A. 1976. Paleocene benthonic foraminiferal biostratigraphy and paleoecology of Tunisia. Bulletin de Centre de Recherches Pau-SNPA, 10, 379- 469.

Bender, H. 1995. Test structure and classification in agglutinated foraminifera. In: Proceedings of the Forth International Workshop on Agglutinated Foraminifera (eds. Kaminski, M.A., Geroch, S. \& Gasinski, M.A.). Grzybowski Foundation Special Publication, 3, 27-70.

Berggren, W.A. 1971. Micropaleontology and Cenozoic paleoclimatology, part II: 277-299. In: Influence of the Continental drift on the distribution of the Tertiary benthic foraminifera in the Caribbean and Mediterranean regions (eds. Berggren, W.A. \& Phillips, J.D.). Symposium on the geology of Libya (ed. Gray, C.), University of Libya, Faculty of Science, Tripoli, 263-299.

Berggren, W.A. 1974. Late Paleocene-Early Eocene benthonic foraminiferal biostratigraphy and paleoecology of Rockall Bank. Micropaleontology, 20 (4), 426-448.
Berggren, W.A. 1978. Recent advances in Cenozoic planktonic foraminiferal biostratigraphy, biochronology, and biogeography: Atlantic Ocean. Micropaleontology, 24, 337-370.

Bindiu, R., Filipescu, S. \& Bălc, R. 2013. Biostratigraphy and paleoenvironment of the Upper Cretaceous deposits in the northern Tarcău Nappe (Eastern Carpathians) based on foraminifera and calcareous nannoplankton. Geologica Carpathica, 64, 117-132.

Bolli, H.M., Beckmann, J.P. \& Saunders, J.B. 1994. Benthic foraminiferal biostratigraphy of the south Caribbean region. Cambridge University, Cambridge.

Boukhary, M., Abdeen, M.M. \& Alsharhan, A.S. 2003. Stratigraphical setting and structural evolution of Jabal Malaqet, northern Oman Mountains, United Arab Emirates. Neues Jahrbuch für Geologie und Paläontologie, 8, 477-497.

Carsey, D.O. 1926. Foraminifera of the Cretaceous of central Texas. Bulletin Texas University, 2612, 1-56.

Cherif, O.H., Al-Rifaiy, I.A. \& El Deeb, W.Z. 1992. «PostNappes» early Tertiary foraminiferal paleoecology of the northern Hafit area, south of Al Ain City (United Arab Emirates). Micropaleontology, 38, 37-56.

Cieszkowski, M., Środoń, J., Waśkowska-Oliwa, A. \& Leśniak, T. 2006. Bentonitized tuffites in the Lower Eocene deposits of the subsilesian unit (western outer Carpathians, Poland): Lithology, stratigraphic position and mineral composition. Annales Societatis Geologorum Poloniae, 76, 197-214.

Cushman, J.A. 1926. The foraminifera of the Velasco Shale of the Tampico Embayment. American Associaion of Petroleum Geology Bulletin, 10, 581-612.

Cushman, J.A. 1931. The Foraminifera of the Saratoga Chalk. Journal of Paleontology, 5, 297-315.

Cushman, J.A. 1946. Upper Cretaceous Foraminifera of the Gulf Coastal Region of the United States and adjacent areas. United States Geological Survey, Professional Paper, 206, 1-241.

Cushman, J.A. \& Hanna, G.D. 1927. Foraminifera from the Eocene near Coalinga, California. California Academic Science, Proceedings, $4^{\text {th }}$ Series, 16, 205-228.

El-Dawy, M.H. 2001. Paleocene benthic foraminiferal biostratigraphy and paleobathymetry, El Sheikh Fadl and Ras Gharib, Eastern Desert, Egypt. Micropaleontology, 4, 23-46.

Filipescu, S. \& Kaminski, M.A. 2008. Paleocene Deepwater agglutinated foraminifera in the Transylvanian. In: Proceedings of the Seventh International Workshop on Agglutinated Foraminifera. (eds. Kaminski, M.A. \& Coccioni, R.). Grzybowski Foundation Special Publication, 13, 25-30.

Friedberg, W. 1901. Otwornice warstw inceramowych Rzeszowa i dębicy. Rozprawy wydzialu matematycznoPrzyrodniczego Akademii Umiejętności, ser. 3, tom 1, Dzial B (Ogólnego Zbioru Tom 41, Dzial I B), Nauki Biologiczne, 601-668.

Galeotti, S., Kaminski M.A., Coccioni, R. \& Speijer, R.P. 2004. High-resolution Deep-Water Agglutinated 
Foraminiferal record across the Paleocene/Eocene transition in the Contessa Road section (central Italy). In: Proceedings of the Sixth International Workshop on Agglutinated Foraminifera (eds. Bubík, M. \& Kaminski, M.A.). Grzybowski Foundation Special Publication, 8, 83-103.

Geroch, S. \& Kaminski, M.A. 1992. The morphology, paleoecology and systematics of Nothia excelsa (Grzybowski), a deep-water agglutinated foraminifera. Annales Societatis Geologorum Poloniae, 62, 255-265.

Glaessner, M.F. 1937. Studien über Foraminiferen aus der Kreide und dem Tertiär des Kaukasus. I. Die Foraminifern der Ältesten Tertiärschichten des NordwestKaukasus. Problemy Paleontologii, Paleontologicheskava Laboratotiya Moskovskogo Gosudarstvennogo Universiteta, 2-3, 349-410.

Grzybowski, J. 1896. Otwornice czerwonych ilów z Wadowic. Akademia Umieietności w Krakowie, Wydzial Matematyczno, Przyrodniczy, Series 2, 10, 261-308.

Grzybowski, J. 1898. Otworina poktadow naftonosych okolicy Krosna (Foraminifera of the oil-bearing beds in the vinicity of Krosna). Akademia Umieietności $w$ Krakowie, Wydzial Matematyczno - Przyrodniczy, Series 2, 13, 257-305.

Hamdan, A.R. \& Anan, H.S. 1993. Cretaceous/Tertiary boundary in United Arab Emirates. Middle East Research Center, Ain Shams University, Earth science series, 7, 223-231.

Hanzlíková, E. 1972. Carpathian Upper Cretaceous foraminifera of Moravia (Turonian-Maastrichtian). Akademii, nakladatelstvi Československé akademie věd, 5.

Haq, B.U., Hardenbol, J. \& Vial, P.R. 1987. Chronology of fluctuating sea level since the Triassic. Science, 235, 1156-1167.

Haque, A.F.M.M. 1956. The foraminifera of the Ranikot and the Laki of the Nammal Gorge, Salt Range, Pakistan. Pakistan Geological Survey Memoir, Palaeontologica Pakistanica, 1, 1-229.

Haynes, J. \& Nwabufo-Ene, K. 1998. Foraminifera from the Paleocene phosphate beds, Sokoto, Nigeria. Revista Española de Micropaleontología, 30, 51-76.

Hewaidy, A.A. \& Al-Hitmi, H. 1993. Cretaceous-Early Eocene foraminifera from Dukhan oil field, west Qatar, Arabian Gulf (A-Suborders Textulariina, Involutinina and Miliolina). Al-Azhar Bulletin of Science, 4, 495-516.

Hewaidy, A.A. \& Strougo, A. 2001. Maastrichtian-lower Eocene benthic foraminiferal distribution and paleoecology of three outcrop sections in Farafra. Egyptian Journal Paleontology, 1, 1-22.

Hulsbos, R.E., Kroon, D. Jansen, H.S.M. \& Van Hinte, J.E. 1989. Lower Eocene benthic foraminifera and paleoenvironment of the outer Vøring Plateau, Norwegian Sea (DSDP Site 338). Micropaleontology, 35, 256-273.

Jones, T.R. \& Parker, T.R. 1860. On the Rhizopodal fauna on the Mediterranean, compared with that of the Italian and some other Tertiary deposits. Quarterly Journal of the Geological Society of London, 16, 292-307.

Kaiho, K. 1988. Uppermost Cretaceous to Paleocene bathyal benthonic foraminiferal biostratigraphy of Japan and
New Zealand: Latest Paleocene-Middle Eocene benthic foraminiferal species turnover. Revue de Paléobiologie, Special Volume 2 (Benthos'86), 553-559.

Kaminski, M.A. 2004. The year 2000 classification of the agglutinated foraminifera. In: Proceedings of the Sixth International Workshop on Agglutinated Foraminifera (eds. Bubík, M. \& Kaminski, M.A.). Grzybowski Foundation Special Publication, 8, 257-271.

Kaminski, M.A. \& Gradstein, F.M. 2005. Atlas of Paleogene cosmopolitan deep-water agglutinated foraminifera. Grzybowski Foundation Special Publication, 10, Grzybowski Foundation, Kraków.

Kaminski, M.A., Gradstein, F.M., Berggren, W.A., Geroch, S. \& Beckmann, J.P. 1988. Flysch-type agglutinated foraminiferal assemblages from Trinidad: taxonomy, stratigraphy and paleobathymetry. Abhandlungen der Geologishen Bundesanstalt, 41, 155-228.

Kender, S., Kaminski, M.A. \& Jones, R.W. 2009. Early to middle Miocene foraminifera from the deep-sea Congo Fan, offshore Angola. Micropaleontology, 54, 477-568.

Kipriyanova, F.V. 1960. Nekotorye peschanye foraminifery iz Melovykh i Paleogenovykh otlozheniy Zaural'ya ]Some arenaceous foraminifera from Cretaceous and Paleogene deposits of the Transurals[. Trudy Gorno-geologicheskogo Instituta. Akademiya Nauk SSSR. Ural'skiy Filial, 51, 73-87.

Krasheninnikov, V.A. \& Pflaumann, U. 1977. Zonal stratigraphy and planktonic foraminifers of Paleogene deposits of the Atlantic Ocean to the west off Africa (DSDP, Leg 41). DSDP Initial Report, 41, 581-611.

Kuhnt, W. \& Collins, E.S. 1996. Cretaceous to Paleogene benthic foraminifers from the Iberia Abyssal Plain. In: Proceedings of the Ocean Drilling Program, Scientific Results (eds. Whitmarsh, R.B., Sawyer, D.S., Klaus, A. \& Masson, D.G.), 149, 203-216.

Kuhnt, W. \& Kaminski, M.A. 1993. Changes in the community structure of deep water Agglutinated foraminifers across the K/T boundary in the Basque Basin (Northern Spain). Revista Española de Micropaleontología, 25, 57-92.

LeRoy, L.W. 1953. Biostratigraphy of Maqfi section, Egypt. Geological Society of American Memoir, 54, 1-73.

Loeblich, A.R. \& Tappan, H. 1987. Foraminiferal genera and their classification. Van Nostrand Reinhold (VNR), New York.

Luger, P. 1985. Stratigraphie der marinen Oberkreide und des Alttertiars im sudwestlichen Obernil-Becken (SW-Agypten) under besonderer Berucksichtig, der Micropaläontologie, Palökologie und Paläogeographie. Berliner Geowiss. Abh., (A), 63, 1-151.

Meulenkamp, J.E. \& Sissingh, W. 2003. Tertiary paleogeography and tectonostratigraphic evolution of the Northern and Southern Peri-Tethys platforms and the intermediate domains of the African-Eurasian convergent plate boundary zone. Palaeogeography, Palaeoclimatology, Palaeoecology, 196, 209-228.

Mjatliuk, E.V. 1966. K voprosu o foraminiferakh c kremnevnym skeletom [On the question of foraminifera with a siliceous skeleton]. Voprosyuznogo Mikropaleontologii, 10, 255-269. 
Mjatliuk, E.V. 1970. Foraminifery flishevych otlozheniivostochnych Karpat (mel-paleogen). Trudy Vsesoyuznogo Nauchno-Issledovatel'skogo Geologorazvedochnogo Instituta VNIGRI, 282, 4-225.

Moore, Jr., T.C., van Andel, Tj.H., Sancetta, C. \& Pisias, N. 1978. Cenozoic hiatuses in pelagic sediments. Micropaleontology, 24 (2), 113-138.

Morgiel, J. \& Olszewska, B. 1981. Biostratigraphy of the Polish External Carpathians based on agglutinated foraminifera. Micropaleontology, 27, 1-30.

Neagu, T. 1968. Biostratigraphy of Upper Cretaceous deposits in the southern Eastern Carpathians near Brasov. Micropaleontology, 14, 225-241.

Nolan, S.C., Skelton, P.W., Clissold, B.P. \& Smewing, J.D. 1990. Maastrichtian to early Tertiary stratigraphy and paleogeography of the Central and Northern Oman Mountains. In: The Geology and Tectonics of the Oman Region (eds. Robertson, A.H.F., Searle, M.P. \& Ries, A.C.). Geological Society of London, Special Publication, 49, 495-519.

Nomura, R. \& Brohi, I.A. 1995. Benthic foraminiferal fauna during the time of the Indian-Asian contact, in southern Balochistan, Pakistan. Marine Micropaleontology, 24, 215-238.

Noweir, M.A. \& Eloutefi, N.S. 1997. The structure and stratigraphy of Jabal Malaqet-Jabal Mundassa area, Southeast Al-Ain, Northern Oman Mountains, United Arab Emirates. Neues Jahrbuch für Geologie und Paläontologie, Abh., 204, 263-284.

Orbigny, A. d'. 1840. Mémoire sur les foraminifères de la craie blanche du bassin de Paris. Mémoires de la Société Géologique de France, 4, 1-51.

Parker, W.K. \& Jones, T.R. 1865. On some foraminifera from the North Atlantic and Arctic oceans, including Davis Strait and Baffins Bay. Philosophical Transactions Royal Society, 155. 325-441.

Phillips, J. D. 1971. Sea floor spreading and continental drift reconstructions around the Atlantic, part I: 266-276. In: Influence of the Continental drift on the distribution of the Tertiary benthic foraminifera in the Caribbean and Mediterranean regions (eds. Berggren, W.A. \& Phillips, J.D). Symposium on the geology of Libya (ed. Gray, C.), University of Libya, Faculty of Science, Tripoli, 263-299.

Proto Decima, F. \& Bolli, H.M. 1978. Southeast Atlantic DSDP Leg 40 Paleogene benthic foraminifers. Initial Report of the Deep Sea Drilling Project, 40, 783-809.

Proto Decima, F. \& De Biase, R. 1975. Foraminiferi bentonici del Paleocene, dell' Eocene inferiore e medio. In: Braga, G. et al:: Foraminiferi bentonici del Paleocene ed Eocene della sezione di Possagno. Schweizerische Paläontologische Abhandlungen, 97, 87-98.
Rosenbaum, G., Lister, G.S. \& Duboz, C. 2002. Relative motions of Africa, Iberia and Europe during Alpine orogeny. Tectonophysics, 359, 117-129.

Reuss, A.E. 1845. Die Versteinerungen der Böhmischen Kreideformation Abtheilung 1. E. Schweizerbart'sohn Verlagsbuchhandlung, 1, 1-58.

Reuss, A.E. 1860. Die Foraminiferen der Westphälischen Kreideformation. Stzungsbrichte der Wissenschaften Wien, Mathematisch-Naturwissenshaftiche Klasse, 40, 147-238.

Rögl, F. 1999. Mediterranean and Paratethys. Facts and hypotheses of an Oligocene to Miocene paleogeography (short overview). Geologica Carpathica, 50 (4), 339-349.

Said, R. \& Kenawy, A. 1956. Upper Cretaceous and Lower Tertiary foraminifera from northern Sinai, Egypt. Micropaleontology, 2, 105-173.

Saint-Marc, P. \& Berggren, W.A. 1988. A quantitative analysis of Paleocene benthic foraminiferal assemblages in central Tunisia. Journal of Foraminiferal Research, 18 (2), 97-113.

Sliter, W.V. 1977. Cretaceous benthic foraminifers from the western South Atlantic Leg 39. Deep Sea Drilling Project, 30, 657-697.

Speijer, R.P. 1994. Extinction and recovery patterns in benthic foraminiferal paleocommunities across the Cretaceous/ Paleogene and Paleocene/Eocene boundaries. Geologica Ultraiectina, Universiteit Utrecht, 124, 1-191.

Speijer, R.P. 2003. Systematics and paleoecology of the foraminifer Neoeponides duwi (Nakkady) from the Paleocene of Egypt. Micropaleontology, 49, 146-150.

Sztrákos, K. 2005. Paleocene and lowest Eocene foraminifera from the north Pyrenean trouph (Aquitaine, France). Revue de Micropaleontologie, 48, 175-236.

Tjalsma, R.C. \& Lohmann, G.P. 1983. Paleocene-Eocene bathyal and abyssal benthic foraminifera from the Atlantic Ocean. Micropaleontology, Special Publication, 4, 1-90.

Vail, P.R., Mitchum, R.M. \& Thompson, S.III 1977. Seismic stratigraphy and global changes of sea level. Stratigraphic Interpretation of Seismic Data. In: Seismic stratigraphyApplications to Hydrocarbon Exploration (ed. Payton, C.E.). American Association of Petroleum Geologists Memoir, 26, 83-97.

Warrak, M. 1996. Origin of the Hafit structure: implications for timing the Tertiary deformation in the Northern Oman Mountains. Journal of Structural Geology, 18, 803-818.

Weidich, K.F. 1988. On the variability of some recent and fossil "Clavulina" species (foraminifera). Abhandlungen Geologie, 41, 337-354.

Zachos, J.C., Lohmann, K.C., Walker, J.C.G. \& Wise, S.W. 1993. Abrupt climate change and transient climates during the Paleogene: A marine perspective. Journal of Geology, $101,191-213$. 
